\title{
De mistério e de letras: nenhum caminho por trás da linguagem?
}

\author{
Vinícius Nicastro Honesko \\ UNICAMP
}

\begin{abstract}
Resumo
A partir da análise da compreensão de revelação - desde a perspectiva teísta católica até seus contemporâneos questionamentos filosóficos - o presente ensaio procura trabalhar com o problema da constituição da linguagem humana, ao menos em certo âmbito da tradição ocidental. Para tanto, de acordo com a concepção da poesia de Paul Valéry, "I’hésitation prolongée entre le son et le sens", e tocando os problemas da questão mística da linguagem - da cabala à filosofia da linguagem -, propõe uma leitura da onto-teo-lógica da linguagem, desde certos pressupostos da cabala até os recentes debates acerca da linguagem e do sentido estabelecidos, sobretudo, por Giorgio Agamben e Jean-Luc Nancy. Procura evidenciar a indagação do mistério do sentido e, assim, expor como a linguagem humana - como voz articulada - esbarra num imponderável (o silêncio como dimensão negativa, uma Voz) e, tal como preconizou Jacques Derrida, só pode se estruturar como borda. Por fim, apresenta como uma noção de jogo de letras, de construção de sentidos, arranja-se como a possibilidade da linguagem poética: não uma comunicação, mas revelação e ex-posição para além da prisão no pressuposto comunicacional, qual seja, o impronunciável nome (não) divino.
\end{abstract}

Palavras-chave: revelação; linguagem; Voz; ex-posição; sentido.

\section{Résumé}

À partir de l'analyse de la compréhension de révélation - du point de vue théiste catholique jusqu'aux questionnements philosophiques contemporain sur le thème - le présent essai cherche à travailler avec le problème de la constitution du langage humaine, au moins dans un certain domaine de la tradition occidental. Pour autant, selon la conception de la poésie de Paul Valéry, « l'hésitation prolongée entre le son et le sens ", et en touchant les problèmes de la question mystique du langage - de la cabale à la philosophie du langage -, il propose une lecture de la onto-théo-logique du langage, depuis certaines présupposés de la cabale jusqu'aux récents débats, établis surtout par Giorgio Agamben et Jean-Luc Nancy, sur le langage et le sens. Il cherche à mettre en évidence la quête du mystère du sens et, de cette façon, à exposer comment le langage humain - comme voix articulée - heurte contre un impondérable (le silence comme dimension négative, une Voix) et, comme a préconisé Jacques Derrida, peut seulement se structurer comme bord. Par fin, il présente comme une notion de jeu de lettres, de construction de sens, s'arrange comme la possibilité du langage poétique : pas une communication, mais révélation et ex-position au-delà de la prison dans le présupposé communicationnel, c'est à dire, l'imprononçable nom (non) divin.

Mots-clés: révélation; langage; Voix; ex-position; sens. 
La Bestia assassina.

La Bestia che nessuno mai vide.

La Bestia che sotterraneamente

falsamente mastina

ogni giorno ti elide.

La Bestia che ti vivifica e uccide...

io solo, con un nodo in gola, sapevo. É dietro la Parola.

Giorgio Caproni

O Catecismo da Igreja Católica - estabelecido no dia 11 de outubro de 1992, no pontificado de João Paulo II e cujo projeto de estruturação e redação fora iniciado em 1986 pelo então cardeal Joseph Ratzinger -, em sua primeira parte ( $A$ Profissão de fé), mais especificamente no capítulo terceiro da primeira seção, Eu Creio - Nós Cremos, traz o querigma do conhecimento de Deus segundo a Igreja. Logo na abertura do capítulo há uma citação da compilação dos dogmas católicos feita por Heinrich Joseph Dominicus Denzinger, em 1854, Enchiridion symbolorum, definitionum et declarationum de rebus fidei et morum, na qual se diz que a razão humana é possuidora da capacidade de conhecer Deus com certeza a partir das coisas criadas. O catecismo completa-a dizendo que sem tal capacidade seria impossível ao homem acolher a revelação de Deus.

No catecismo está elaborada uma compreensão das dificuldades históricas a respeito do conhecimento de Deus. Nada de novo, com efeito, em relação à tradição católica que desde há muito lida com o tema. Exemplar nesse sentido, entretanto, é a proposição que a Encíclica Humani generis, de Pio XII, declara logo na sua introdução:

Não é de admirar que haja constantemente discórdias e erros fora do redil de Cristo. Pois, embora possa realmente a razão humana com suas forças e sua luz natural chegar de forma absoluta ao conhecimento verdadeiro e certo de Deus, único e pessoal, que sustém e governa o mundo com sua providência, bem como ao conhecimento da lei natural, impressa pelo Criador em nossas almas, entretanto, não são poucos os obstáculos que impedem a razão de fazer uso eficaz e frutuoso dessa sua capacidade natural. De fato, as verdades que se referem a Deus e às relações entre os homens e Deus transcendem por completo a ordem dos seres sensíveis e, quando entram na prática da vida e a enformam, exigem o sacrifício e a 
abnegação própria. Ora, o entendimento humano encontra dificuldades na aquisição de tais verdades, já pela ação dos sentidos e da imaginação, já pelas más inclinações, nascidas do pecado original. Isso faz com que os homens, em semelhantes questões, facilmente se persuadam de ser falso e duvidoso o que não querem que seja verdadeiro.

Por isso deve-se defender que a revelação divina é moralmente necessária para que, mesmo no estado atual do gênero humano, todos possam conhecer com facilidade, com firme certeza e sem nenhum erro, as verdades religiosas e morais que não são por si inacessíveis à razão.

Ademais, por vezes, pode a mente humana encontrar dificuldade mesmo para formar juízo certo sobre a credibilidade da fé católica, não obstante os múltiplos e admiráveis indícios externos ordenados por Deus para se poder provar certamente, por meio deles, a origem divina da religião cristã, exclusivamente com a luz da razão. Isso ocorre porque o homem, levado por preconceitos, ou instigado pelas paixões e pela má vontade, não só pode negar a evidência desses sinais externos, mas também resistir às inspirações sobrenaturais que Deus infunde em nossas almas. ${ }^{1}$

O catecismo, ao comentar tal encíclica, salienta que "o homem tem necessidade de ser iluminado pela revelação de Deus, não somente sobre o que ultrapassa o seu entendimento," ${ }^{2}$ mas também sobre aquilo que por si só não é inacessível à razão, mas que, pelo atual estado histórico humano, torna-se difícil de ser compreendido.

Revelação, no sentido dos teólogos católicos, portanto, é uma espécie de suporte para os limites da razão; ou seja, é o que abre ao entendimento humano (à sua razão - ao seu logos) aquilo que apenas o próprio Deus pode mostrar (ou, ainda, possibilita a clarificação de situações que, ainda que acessíveis à razão, somente se reveladas por Deus são compreendidas). A partir dessa construção conceitual católica, se aquilo que a revelação dá ao conhecimento humano fosse acessível à razão, revelação cessaria de ser revelação. Além disso, a revelação divina, como atesta a Humani generis, é necessária como condição e possibilidade do conhecimento em geral.

A partir de um trecho da Carta aos Colossenses de Paulo, quando este afirma seu encargo de ministro do corpo de Cristo "para levar a bom termo o anúncio da Palavra de Deus, o mistério escondido desde os séculos e desde as gerações, mas agora manifestado aos seus santos” (Col, 1: 25-26) ${ }^{3}$, Giorgio Agamben expõe como o termo mistério, em tal passagem, opõe-se à palavra de Deus. Segundo o filósofo italiano - que desestabiliza, em sua leitura, a hermenêutica católica do texto - o que se esconde no mistério não é algo concernente ao presente mundo ou ao mundo futuro, mas apenas à própria palavra de Deus. ${ }^{4}$ A revelação de um mistério, nesse sentido, é a experiên-
1. PIO XII. Humani Generis.

Sobre opiniões falsas que ameaçam a doutrina católica..

\section{CATECISMO DA IGREJA CATÓLICA, 1993, p. 25.}

3. As referências do texto bíblico são feitas a partir da seguinte versão: $A$ Bíblia de Jerusalém. São Paulo: Paulus, 1995.

4. Cf. AGAMBEN, Giorgio. La Potenza del Pensiero. Saggi e conferenze, 2005, p. 26. 
5. NANCY, Jean-Luc.

L'évidence du mystère. In: Le Voyage Initiatique, 2011, pp. 89-90. Todas as citações feitas de obras em outras línguas que não o português foram traduzidas pelo autor. cia mais comum, a mais banal, da ocupação do homem com a linguagem e com o mundo aberto das significações. Não há desvelamento de um algo escondido, mas somente pura exposição do próprio logos, da linguagem na sua possibilidade de ser proferida.

Também Jean-Luc Nancy, nos traços das Paixões de Jacques Derrida, fala que no mistério não há um conteúdo de significados a ser revelado, mas infinito de sentidos que se abre nos nomes próprios e que retira a pergunta imediata que se faz diante do mistério - “o que isso quer dizer?” -, pois não há sentido último (uma espécie de verdade do ser), mas o infinito de sentidos do mundo aberto pela linguagem. Isto é,

não há um mistério que esperaria ser desvelado e que nos revelaria um sentido escondido. Não há um sentido último, mas há um "infinito do sentido", a fórmula foi pronunciada. Esse infinito do sentido não é nada que nós poderíamos tomar, nada que nós, tampouco, poderíamos figurar e, ainda menos, do qual poderíamos fazer para nós algo como um deus, para não falar de um ídolo. (...) É por isso que diante de um homem ou de uma mulher, obviamente, o que nós chamamos uma "pessoa", isto é, algo, se assim posso dizer, que está antes de tudo apresentado por um rosto e um nome - e o nome diz a verdade do rosto -, estou diante de uma singularidade, e é a respeito dessa singularidade que o nome, o nome próprio, diz-me algo. Ora o nome próprio, como sabemos pela boa linguística, não quer dizer nada, mesmo se é transferência de um nome comum. E apenas o rosto, assim que ele me apresenta traços, aspectos, olhares, mostra-me também que não me entrega a intimidade da pessoa. E que talvez ela não pode ser entregue, significada. ${ }^{5}$

O olhar para as coisas - um olhar que é já sempre atravessado pela linguagem - revela o mundo, o infinito de sentidos das relações singulares das coisas e nomes.

É nesse sentido, creio, que a experiência do mistério é, no fundo, a experiência, ousaria dizer, mais comum. Ela é a experiência que acontece assim que nós não estamos ocupados com outra coisa - e "outra coisa" é evidentemente o que é sem mistério, que pode conter muitos supostos mistérios, isto é, de fato, segredos, coisas que não conhecemos, truques a serem encontrados, receitas a aprender, competências a manejar quando assim o podemos, se nós podemos. Mas isso que se produz sem cessar não é mistério. Melhor dizendo, não é concedido, da manhã à noite, em cada minuto, encontrar-se diante do mistério sem segredo, mas isso se produz por momentos - se a isso prestamos atenção. E, penso, além disso, que é muito simples e muito evidente dizer que, sem isso, nós não continuaríamos a viver numa humanidade tão difícil, que 
deixa a vida tão difícil. Nós continuamos porque sabemos algo do mistério de cada um, homem, animal, planta, e do mistério deste mundo que nós transformamos sem cessar. Nós sabemos que é o mistério de um sentido infinito. ${ }^{6}$

Revelar o sentido de um mistério não é desvendar o ser por trás do significante linguístico, um absoluto - que poderia, inclusive, ser o Absoluto, o deus absconditus no mundo, o $\operatorname{logos}$ joanino -, uma razão última que determinasse o sentido da revelação, pois

tudo quanto existe é sua própria razão, não tem nenhuma outra, o que não quer dizer que seja em si mesmo princípio e fim, já que não é "si mesmo". É sua própria dis -posição como pluralidade de singularidades. Esse ser se ex-põe então como o entre e como o com dos singulares. Ser, entre e com dizem a mesma coisa: dizem precisamente o que não pode mais que ser dito (o que se denominaria, por outro lado, “o inefável”), o que não se pode apresentar como um ente entre outros, já que é o "entre" de todos os seres (entre: dentro, em meio de, com) que são todos e a cada vez uns entre outros. Ser não diz nada distinto e, em consequência, se o dizer diz sempre o ser de uma maneira ou outra, em troca o ser não se expõe mais do que no incorpóreo do dizer. ${ }^{7}$

O conhecimento revelado é a revelação do sentido do que se dá como existente, e não há, por trás deste, senão a própria exposição da incorporalidade do dizer. Assim, o que a razão - para voltar aos termos dos teólogos católicos - não pode conhecer por si, um suposto (pressuposto) não linguístico da linguagem (o inefável divino), só pode significar que o

conteúdo da revelação não é uma verdade exprimível sob a forma de proposições linguísticas sobre o existente (ainda que se tratasse do ente supremo), mas, muito mais, uma verdade que concerne à própria linguagem, ao fato de que a linguagem (e, portanto, o conhecimento) seja. O sentido da revelação é que o homem pode revelar o existente através da linguagem, mas não pode revelar a própria linguagem. Em outras palavras: o homem vê o mundo através da linguagem, mas não vê a linguagem. Esta invisibilidade do revelador naquilo que ele revela é a palavra de Deus, é a revelação. ${ }^{8}$

A revelação não porta à luz um segredo, uma proposição significante com determinado valor léxico (isto é, uma realidade escondida do mundo ou do além-mundo), mas apenas o velamento em si que é revelado. Em outras palavras: se um segredo é mantido apenas na medida em que o seu significado permanece escondido no discurso não-dito que explicitaria o conteúdo (a significação lexical, portanto) omitido por aquele
6. Ibidem, pp. 90-91.

7. NANCY, Jean-Luc. Ser Singular Plural, 2006, p. 102.

8. AGAMBEN, Giorgio. $\mathrm{La}$ Potenza del Pensiero. Saggi e conferenze, 2005, p. 26. 
9. Cf. VIRNO, Paolo. Quando il verbo si fa carne. Linguaggio e natura umana, 2003.

10. WITTGENSTEIN, Ludwig. Tractatus Logico-philosophicus, 1968, p. 128.

11. AGAMBEN, Giorgio. La Potenza del Pensiero. Saggi e conferenze, 2005, p. 27. que mantém o segredo, a revelação revela apenas o lugar do discurso, isto é, que existe a linguagem. Revelar é o ato de indicar o lugar do discurso, apontar para o ter-lugar da palavra humana. Desse modo, se o segredo está retido na intenção de significação de um sujeito que fala, isto é - e lembrando a sugestão de Paolo Virno a respeito de uma dupla dimensão da linguagem: aquilo que se diz e o fato de que se fala ${ }^{9}$-, é um jogo entre o que é dito e o que se quer dizer (a própria funcionalidade da linguagem na relação significante/significado), jamais pode, entretanto, impedir a revelação. Esta é a exposição irremediável de um fato: fala-se, ou seja, o discurso tem lugar.

No texto cardinal da tradição cristã, a abertura do evangelho de João, o Verbo demora no Pai:

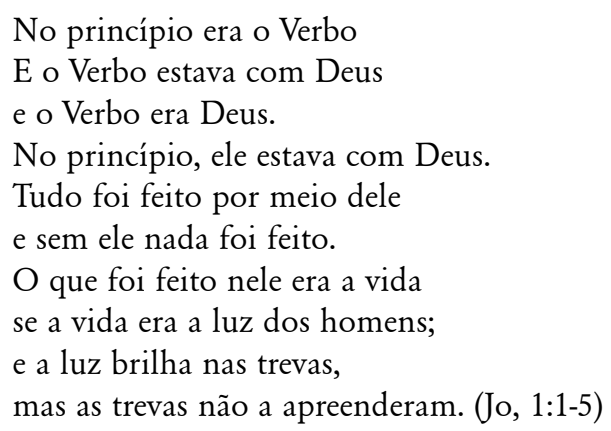

Mas ele, o Verbo, não é senão uma espécie de silêncio em que o que é velado inexoravelmente se revela no existente: o inefável, o pressuposto silencioso da linguagem, estava em Deus e era deus - e, assim, podemos ler na proposição 6.44 do Tractatus de Wittgenstein a exposição de seu místico como o linguístico: "O que é místico não é como o mundo é mas que ele seja” ${ }^{10} \mathrm{E}$ que ao longo dos séculos, na chamada cultura ocidental, o início do texto de João tenha sido equacionado pelos teólogos nas doutrinas da economia trinitária, diz que, para além do infinito de sentidos, no catolicismo (e, em geral, no protestantismo) o sentido último é que permanece como o próprio velado às condições de racionalidade do homem - e daqui a revelação apregoada na catequética católica. Entretanto, quando João expõe como princípio o Verbo - a Palavra -, este não pressupõe nada além de si mesmo. "Não há nada antes dela [a palavra] que possa explicá-la ou, por sua vez, revelá-la (não há palavra para a palavra) e sua estrutura trinitária não é nada além do movimento de sua própria auto-revelação." ${ }^{11}$ O não-pressuposto absoluto que, por sua vez, é o pressuposto por excelência, é o próprio Verbo, isto é, o próprio Deus.

A revelação é a exposição do lugar que transcende toda palavra e conhecimento humanos (em termos contemporâneos: a revelação exerce uma função de metalinguagem que, no entanto, não tem função significante, mas apenas a indicação 
insignificante do ter-lugar da linguagem). Por outro lado, porém, não mostra nada além da própria linguagem, do lugar do discurso, do fato de que a linguagem existe. Assim como a $V_{0 z}{ }^{12}$ e como o nome (onoma) - e também o inefável místico - a revelação evidencia o fundo negativo sobre o qual a palavra humana parece se fundar; o infundamento que é o fundamento - a auto-pressuposição - do logos. ("Que haja linguagem é de tal modo certo quanto incompreensível, e esta incompreensibilidade e esta certeza constituem-se na fé e na revelação.”13).

$\mathrm{O}$ fundamento negativo, no entanto, também tem outro nome, o outro nome do ser, o outro nome de Deus: nada. E, preso à lógica da linguagem significante, o nada que sobeja o ser é o silêncio que fundamenta a linguagem. Jacob Taubes, intentando uma interpretação ontológica da teologia, pergunta-se: "O nada, pode ser expressado de maneira significativa?" Ao que responde:

O nada nunca pode ser um objeto, mas, enquanto sujeito, precede sempre e em todas as partes qualquer coisa. Quando a linguagem está reduzida aos limites que fixa a lógica dos objetos, o nada não pode ser expressado. A linguagem deve estar livre da sujeição da lógica dos objetos. Na rede da lógica dos objetos não há verdadeiramente um sujeito e a distinção gramatical entre sujeito e objeto é confusa e enganosa. Como se distingue, pois, o sujeito de uma proposição ontológica do objeto lógico? Ambos são objetos. Não somente falha aqui a linguagem; a lógica dos objetos não está em condições de expressar o sujeito ontológico. Se a linguagem se vir liberada dessa lógica, talvez poderia expressar-se nela até o silêncio. ${ }^{14}$

A linguagem arquitetada numa lógica de objetos (numa lógica de predicados, diria Agamben), está ligada ao como é o mundo wittgensteiniano, mas deixa o seu rastro misterioso no que é o mundo: o silêncio inexpresso da existência de algo não mais do que nada. E o Verbo que demorava em Deus é também o nada, porém, que explode no que há, na existência do mundo. Diz Taubes que aí ateísmo e teologia tocam o nada na sua identificação com Deus:

A teologia e o ateísmo ocultam Deus como o nada. Quando, no passado, intentou-se definir a relação entre Deus e o mundo, surgiu a ideia da "creatio ex nihilo". Nessa formulação permanece sem clareza a relação entre o "ex nihilo" e o "a deo", implícita ainda que não seja mencionada. Se Deus cria a criação a partir do nada, ele deve ter uma relação com esse nada. Mas, como pode ser "relacionado"... com esse nada se Deus é Deus? Somente se se trata de uma "relação" de identidade, se "deus" e "nihil" são idênticos. Então, "creatio ex nihilo" significa uma "creatio ex deo". Mas se "creatio ex nihilo a deo" significa "creatio
12. Cf. AGAMBEN, Giorgio. El Lenguaje y la Muerte. Un seminario sobre el lugar de la negatividad, 2002; AGAMBEN, Giorgio. Infância e História. A destruição da experiência e a origem da história, 2005.

13. AGAMBEN, Giorgio. $L a$ Potenza del Pensiero, 2005, pp. 29-30.

14. TAUBES, Jacob. Del culto a la cultura. Elementos para una critica de la razón histórica, 2007, p. 264. 
15. Ibidem, p. 265.

16. NANCY, Jean-Luc. Ser Singular Plural, 2006, p. 101.

17. ANSELMO. Proslogium. Translated From The Latin By Sidney Norton Deane, B. A. With An Introduction, Bibliography, And Reprints Of The Opinions Of Leading Philosophers And Writers On The Ontological Argument (Chicago, The Open Court Publishing Company, 1903, reprinted 1926). ex nihilo a nihilo", qual sentido pode ter então "creatio"? "Ex nihilo fit ens creatum" não se opõe a "ex nihilo nihil fit"? Essa contradição se resolve se Deus e o nada são um. Se "deus" e "nihil" são idênticos, então coincidem "creatio ex nihil" e "ex nihilo nihil fit". "Creatio" significa então o explodir do nada numa multiplicidade de algo. Nessa explosão do nada nasce a multiplicidade de algo. $\mathrm{Na}$ multiplicidade de algo é perceptível o desejo pela unidade da criação nascida da explosão. $\mathrm{O}$ nada retumba com as dores do parto de algo. O nascimento, como explosão do nada na multiplicidade de algo, e a morte, como a fusão da multiplicidade na unidade do nada, voltam-se eternamente um ao outro. ${ }^{15}$

A explosão do nada no existente é a ex-posição da singularidade plural do mundo, e esta só pode ser dita na linguagem, no "infinito de sentidos" de que fala Nancy:

A linguagem é o que expõe a singularidade plural. Nela, todo o existente se expõe como seu sentido, quer dizer, como a participação originária segundo a qual o existente se relaciona com o existente, circulação de um sentido do mundo que não possui nem começo nem fim, que é o sentido do mundo como ser-com, a simultaneidade de todas as presenças que são todas, umas em respeito às outras, e das que nenhuma é em si sem ser com as demais. ${ }^{16}$

Um tal "infinito de sentidos" da explosão do nada na maravilha do existente jamais pode estar presente numa compreensão de revelação teísta como a católica. Ainda numa tradição que remontaria a Anselmo, o nada não esbarra no ser sobre o qual nada maior, nem anterior, pode ser concebido. $\mathrm{O}$ argumento ontológico - a prova da existência de algo por um simples pronunciar de palavras - funciona como um suporte para uma revelação que revelaria o Ser somente por um princípio de razão última.

Nós acreditamos que tu és um ser sobre o qual nada maior pode ser concebido. Ou não há tal natureza, já que o tolo disse no seu coração que não há Deus? (Salmo 14:1). Mas, sob qualquer atributo, esse néscio, quando ouve acerca desse ser do qual falo - um ser sobre o qual nada maior pode ser concebido - compreende o que ouve e aquilo que compreende está no seu entendimento; embora ele não entenda que isso exista. (...) Até mesmo o tolo está convencido de que algo exista ao menos no entendimento, sobre o qual nada maior pode ser concebido. Assim, quando ele ouve sobre isso, ele entende isso. E, não importa o que é entendido, existe no entendimento. E, indubitavelmente, aquilo sobre o qual nada maior pode ser concebido, não pode existir no entendimento sozinho. ${ }^{17}$

Quando o tolo ouve o nome de Deus, o simples fato de 
formular algo em seu pensamento garante a existência da coisa pensada - que no argumento de Anselmo é o próprio Deus. Ou seja, aquilo que é falado por alguém - uma vez que o tolo deve escutar o nome de Deus - é, no argumento, existente. Todavia, enquanto dito que é e não como é, é apenas o lugar pressuponente da linguagem, seu ter-lugar. Assim, em Anselmo, de acordo com Agamben,

um ser cuja simples nominação linguística implica a existência existe: é a linguagem. O fato de que eu fale e de que alguém escute não implica a existência de nada - a não ser da linguagem. A linguagem é aquilo que deve necessariamente pressupor a si mesma. Aquilo que o argumento ontológico prova é, portanto, que, se os homens falam, se existem animais racionais, então existe uma palavra divina, no sentido em que já sempre haja a preexistência da função significante e a abertura da revelação (apenas nesse sentido - isto é, somente se Deus é o nome da preexistência da linguagem, do seu permanecer na arké - o argumento ontológico prova a existência de Deus)..$^{18}$

O problema é que, ao tentar provar a existência de um ser por meio de um discurso dotado de significado, a única coisa provada é a existência do ter-lugar da linguagem, isto é, a existência da linguagem. A ausência do ser que se pretendia provar presente, portanto, lança o teísmo à sua impossibilidade - ou, como lembra Jean-Luc Nancy, num belo ensaio denominado O Nome de Deus em Blanchot, a um ausenteísmo. Nesse mesmo ensaio, diz o filósofo francês:

Se o nome de Deus vem no lugar de uma ausência do sentido, ou como na linha de fuga e na perspectiva ao mesmo tempo infinita e sem profundidade de campo dessa mesma linha de fuga, é antes de tudo porque esse nome não diz respeito a uma existência, mas, precisamente, à nomeação - que não seria nem a designação nem a significação - dessa ausência. Não há aí, portanto, a justo título, nenhuma "questão de Deus" que deveria ser colocada como a questão ritual da existência ou da não-existência de um ente supremo. Semelhante questão se anula por si mesma (sabemos disso desde Kant, aliás, bem antes dele), já que um ente supremo deveria ainda se encontrar em dívida com o seu ser ou com o próprio ser em alguma instância ou em alguma potência (termos evidentemente muito impróprios) impossível de organizar na ordem dos entes. ${ }^{19}$

Uma revelação nada revela, portanto, senão a abertura do espaço do simples discurso, no seu não-revelar um conteúdo discursivo - uma significação -, mas o puro evento da linguagem, aquilo que Agamben denomina como uma dimensão
18. AGAMBEN, Giorgio. La Potenza del Pensiero, 2005, p. 28.

19. NANCY, Jean-Luc. O nome de Deus em Blanchot, 2013. 
20. AGAMBEN, Giorgio. $L a$ Potenza del Pensiero, 2005, p. 29.

21. SCHOLEM, Gershom. Il Nome di Dio e la Teoria Cabbalistica del Linguaggio, 2005, p. 93.

22. E aqui toda a implicação das questões acerca da palavra de ordem e do discurso indireto, analisados por Deleuze e Guattari, pode ser interessante para se pensar os modos da tradição transmissível da verdade. Cf. DELEUZE, Gilles; GUATTARI, Félix. Mil Platôs. Capitalismo e esquizofrenia. Vol. II, 1997. p. 13. "O difícil é precisar o estatuto e a extensão da palavra de ordem. Não se trata de uma origem da linguagem, já que a palavra de ordem é apenas uma função-linguagem, uma função co-extensiva à linguagem. Se a linguagem parece sempre supor a linguagem, se não se pode fixar um ponto de partida não-linguístico, é porque a linguagem não é estabelecida entre algo visto (ou sentido) e algo dito, mas vai sempre de um dizer a um dizer".

23. HEIDEGGER, Martin. $A$ Caminho da Linguagem, 2003, p. 187.

24. SCHOLEM, Gershom. Il Nome di Dio e la Teoria Cabbalistica del Linguaggio, 2005, p. 101. lógica original e além daquilo que na linguagem é dito, isto é, a Voz (ou, revertendo e anulando a conscienciosa revelação teísta, o nada que é Deus). Por isso, "o nome de Deus, isto é, o nome que nomeia a linguagem, é, portanto (como a tradição mística não cessou de repetir), uma palavra sem significado" ${ }^{20}$

Essa identificação entre nada e deus pode ser remetida à ironia cabalista, lembrada por Gershom Scholem, de que há uma tradição em que a verdade do ser pode ser proferida: "O cabalista mantém a ideia de que a verdade tenha uma tradição, de que a verdade possa ser proferida. Afirmação irônica, já que a verdade de que se fala aqui é tudo menos proferível. A verdade pode ser conhecida, mas não transmitida, e exatamente isso que dela é proferível não a contém mais". ${ }^{21}$ Tocada a verdade, pelo fato da existência da linguagem (que o mundo é), nenhum conteúdo auferido do toque - nenhum discurso significante, nenhuma tradição - é capaz de dizer a verdade, de transmiti-la. ${ }^{22} \mathrm{Ou}$ ainda, dizer o misterioso ter-lugar da linguagem (ou, com Heidegger, "o dizer capaz de trazer à linguagem a essência vigorosa a linguagem" ${ }^{23}$ ) não na voz, mas como $V o Z$ - e eis a Besta caproniana por trás da Palavra. A uma verdadeira língua (uma língua pura, diria Benjamin), no tempo histórico (ao menos na tradição ocidental), não se tem acesso.

O inteiro pode ser proferido somente de modo oculto. O Nome de Deus pode ser chamado, mas não pronunciado. Já que somente o que na língua há de fragmentário faz sim com que ela possa ser falada. Não se pode falar a "verdadeira" língua, assim como não se pode cumprir um ato absolutamente concreto. ${ }^{24}$

É possível chamar o nome divino, em outros termos, o Verbo, mas não é possível pronunciá-lo. Um lugar silencioso $\mathrm{da}$ linguagem que aparece, mas que não pode ser visto. No que toca à interpretação catequética católica, é perceptível que os elementos que a teologia cristã declara inapreensíveis pela razão, aquilo que excede os nomes, seriam passíveis de conhecimento pelo homem somente pela revelação. No entanto, tais elementos incompreensíveis (impronunciáveis - portanto, o próprio deus) são o que, insistindo na terminologia católica, a razão reconhece como seu pressuposto, como o silêncio que possibilita a linguagem (uma ausência que é deus). Uma incompreensão a dar suporte à compreensão - isso que, no debate linguístico, nada mais é que o silêncio das palavras. 
Não te machuque a minha ausência, meu Deus,

Quando eu não mais estiver na Terra

Onde agora canto amor e heresia

Outros hão de ferir e amar

Teu coração e corpo. Tuas bifrontes

Valias, mandarim e ovelha, soberba e timidez.

Não temas.

Meus pares e outros homens

Te farão viver destas duas voragens:

Matança e amanhecer, sangue e poesia.

Chora por mim. Pela poeira que fui

Serei, e sou agora. Pelo esquecimento

Que virá de ti e dos amigos.

Pelas palavras que te deram vida

E hoje me dão morte. Punhal, cegueira

Sorri, meu Deus, por mim. De cedro

De mil abelhas tu és. Cavalo-d'água

Rondando o ego. Sorri. Te amei sonâmbula

Esdrúxula, mas te amei inteira.

Hilda Hilst

Não é a literatura, por sua vez, o toque nessa borda plena de silêncio e que, ao mesmo tempo, revela o mundo, que é a linguagem? Ademais, a poesia, como a tarefa do poeta, não é o chamar o nome silencioso, o impronunciável silêncio sempre dito, na linguagem?

Divagações gozosas - e Hilda Hilst, na sua interpelação a Deus, despede-se da palavra em deus - são a porta de acesso à borda em que o poeta, lançando-se na hésitation prolongée entre le son et le sens, brinca tal qual um infante. É a possibilidade de armar, num texto, a brincadeira infantil diante das letras, que, em certo sentido, excede a linguagem enquanto função comunicativa. E esse jogo é também um modo de não se referir a nada útil, mas a algo sutil como uma letra, um gramma, para dizer com Derrida. É curioso como uma letra desloca o emblema máximo dos tempos de capitalismo financeiro doentio ao seu oposto. Os adjetivos útil e sutil, de fato, não são opostos; porém, o primeiro refere-se à necessidade, ao uso determinado e preciso, ao mundo da produção, já o segundo diz respeito a coisas delicadas, pequenas e refinadas (e, outra brincadeira: útil 
é paroxítona - claro, as palavras também podem ser estoicas: primeiro a força para depois ter o descanso numa ética do labor, mesmo que se possa pensar no sexo, se bem que de modo ainda muito cristianizado; sutil é oxítona - o clímax vem aos poucos, é tântrico, é de gozo contínuo com uma explosão final).

Os substantivos utilidade e sutileza conseguem expor, mais que seus adjetivos, figuras desse mundo opositivo. Com frequência se diz que a lógica do mercado é a utilidade, que é imperiosa, que não dá tréguas; a sutileza, por sua vez, seria para momentos precisos (normalmente associados ao "lazer" do homem médio - num discurso ainda dentro da lógica capitalista), não dado às coisas úteis. Em outra linguagem, poderíamos dizer que a utilidade é masculina, enquanto a sutileza é feminina (e isso se agrava ainda mais em estudos biológicos que apontam a caça - coisa verdadeiramente útil - ao macho, enquanto à fêmea restariam os trabalhos menos úteis e mais sutis - a preparação dos alimentos, o cuidado com a cria etc.). É evidente que a distinção pautada no critério da necessidade não é taxativa (aliás, não é questão de dois opostos).

Nesse jogo com um $s$, por exemplo, é possível abrir toda uma temática: com $s$ diz-se sexo, palavra na qual a letra $s$ aparece uma só vez, mas é dita duas. Nada mais gratuito que o sexo (a não ser que, escolástica e cretinamente, alguém queira dizer que sexo é para a reprodução - o que seria reafirmar a lógica da utilidade num espaço em que predomina a sutileza). Foucault foi muito perspicaz ao dizer que diante do minúsculo segredo do sexo todos os enigmas do mundo parecem menores. Mas não se preocupando com os enigmas ditos no mundo, mas tão somente com o das letras, é possível abrir um jogo, como o da letra $s$ (e, anfibologicamente, ao modo de Max Ernst no La Femme 100 têtes, no qual o número 100 funciona como uma caixa de letras - e sons - para uma brincadeira com a sentença: sans tête, cent tête, s'entête, sang tête...).

Pensar a linguagem a partir de uma espécie de jogo de letras é algo feito pela cabala judaica. Toda a experiência mística dos judeus medievais se dava por meio da reflexão sobre o tetragrama sagrado. O nome com o qual deus nomeia a si mesmo é a tal ponto uma experiência da letra, que não pode ser proferido (nomen innominabile). Para o místico, o som e a letra coincidem e daí a força criadora do Nome. A auto-nomeação divina seria como que anterior ao primeiro ato da criação e esta, a criação, seria apenas emanação das letras que compõem o nome divino (daí o caráter impronunciável do nome do deus judeu). Em hebraico a palavra ot não quer dizer apenas letra, mas também signo. Eis a razão de as teorias cabalísticas pensarem as letras como assinaturas secretas (signos secretos) do divino em todos os graus do processo da criação. Isaac o cego - que Scholem diz ser talvez o primeiro cabalis- 
ta provençal passível de ser historicamente individualizado ${ }^{25}$ - dizia que toda letra, como configuração de forças criadoras divinas, representa as formas supremas (divinas) e, ao assumir um aspecto visível no plano terreno, passa a possuir um corpo e uma alma. Esta seria a articulação do espírito divino que vive na letra (proveniente do sopro da criação), de modo que todo o criado está fundamentado na linguagem divina, à qual, porém, os homens não têm acesso. A estes é deixada como herança a maldição de saber reconhecer as letras do nome divino (o tetragrama), porém, a impossibilidade de pronunciá-lo. De certo modo, falamos aqui de uma gramática do inominável, do que não pode ser proferido; isto é, no fundamento (a letra) de toda palavra e de todo proferir (a fonética, a voz), existe uma negação fundamental - a Voz. E, além da cabala judaica, também a gnose tardo-antiga e a mística cristã fazem tal experiência.

Henri-Charles Puech, ao comentar a obra do místico Pseudo-Dionísio Aeropagita, indica como a relação de inadequação da apreensão mística de um sujeito cognoscente e um objeto desconhecido encontra seu ajuste na Treva (as condições para o sujeito ser iniciado e, ao mesmo tempo, como sinal da transcendência divina - de modo simétrico a como o silêncio é condição para o sujeito na espera divina e como Deus mesmo pode ser dito silêncio, Sigé). No caminho do místico ao êxtase, diz Puech,

\begin{abstract}
Nuvem e Obscuridade aqui simbolizam, portanto, a impossibilidade de a união mística esgotar um objeto que permanece fora de toda apreensão, que não pode nem mesmo ser tomado como objeto. Elas marcam o limite que impõe à finitude do sujeito criado o caráter infinito Daquele que o êxtase só pode aproximar. É seguindo essa distância ou essa inadequação jamais colmatada que Aquele que é apenas Luz, ou mesmo que é superior à Luz como à Obscuridade, aparece como Treva. ${ }^{26}$
\end{abstract}

Em certo sentido, portanto, a união extática deixa um descarte, pois a impossibilidade de conhecimento do místico é simétrica à impossibilidade de dar-se a conhecer de Deus. Nessas impossibilidades, poderíamos lembrar com Jacques Derrida, está a marca de uma busca de um conhecimento não-conhecível que, como toda teologia apofática (negativa), é audaz em ir mais longe do que convém permitir. ${ }^{27}$

Em João da Cruz a metáfora da noite escura é um modo de relacionar-se com o negativo, com o aniquilamento de Deus por Deus na experiência do Calvário - isto é, a maior obra divina na experiência de seu próprio aniquilamento. Em seu História do Nada, Sergio Givone lê nessa anulação divina justamente - tal como sugeriu Taubes - a identificação de Deus e nada:
25. Ibidem, pp. 45-53.

26. PUECH, Henri-Charles. En Quête de la Gnose. I. La gnose et le temps, 2006, p. 126.

27. DERRIDA, Jacques. Salvo o Nome, 1995, p. 9. 
28. GIVONE, Sergio. Historia de la Nada, 2001, p. 101.

29. AGAMBEN, Giorgio. La

"Notte Oscura" di Juan de la

Cruz. In: CRUZ, Juan de la.

Poesie, 1974, p. VII.

30. DERRIDA, Jacques. Salvo o Nome, 1995, p. 43.

31. Ibidem, p. 35.
Somente no nada e frente ao nada Deus se reconcilia com o homem e o salva do próprio nada. A potência da negação não deve perdoar nem a Deus nem ao homem. Se perdoasse ao homem, isto é, se o homem encontrasse em algum lugar um pretexto certo no qual ancorar sua existência, poderia prescindir de Deus. E se perdoasse a Deus, Deus encobriria o homem tornando impossível, com seu simples ser, toda reunião com ele. Ao contrário, Deus se abandona à potência da negação, sem subtrair-se a nenhuma forma de autodestruição. Onde pode então o homem encontrar Deus senão ali, na aniquilação da divindade? ${ }^{28}$

Tais misticismos, assim, abrem-se ao paradoxo contido na experiência de um negativo:

Que, enquanto é opacidade e desapossamento integral, a experiência final que ela implica é aquela, puramente negativa, de uma presença que não se distingue em nada de uma ausência; em sentido próprio, ela não é antes uma teologia (uma ciência de Deus), mas uma teo-alogia, que atinge uma incognoscibilidade última ou, ao menos, um conhecer apenas por opacidade e negação, uma apropriação cujo objeto é o próprio Inapropriável, e que não está, por isso, substancialmente em um habitus doutrinal positivo, mas apenas metaforizável e aludível por oximoros, catacreses e outras "figuras e similitudes extravagantes". ${ }^{29}$

Desse modo, a experiência em questão, no êxtase, é a de um tocar a borda da linguagem - ela que dá a única possibilidade de conhecer - e, como lembra Derrida, "somente há borda, somente há limite na linguagem... Quer dizer, referência. Dado que nunca há nada a não ser referência, uma referência irredutível, pode-se também concluir que o referente - tudo, salvo o nome - é ou não é indispensável”. ${ }^{30}$ Assim, a busca fundamental, a busca do fundamental na linguagem - pela via negativa - acaba por esbarrar no limite que é a linguagem mesma. A teologia negativa

não seria somente uma linguagem, e um teste da linguagem, mas antes de tudo a experiência mais pensante, a mais exigente, a mais intratável da "essência" da linguagem, um "monólogo" (no sentido heterológico que Novalis ou Heidegger dão a essa palavra), no qual a linguagem e a língua falam de si mesmas e constatam o que é Die Sprache spricht. De onde essa dimensão poética ou ficcional, às vezes irônica, sempre alegórica, da qual alguns diriam ser somente uma forma, uma aparência ou um simulacro... É verdade que, simultaneamente, essa árida ficcionalidade tende a denunciar as imagens, as figuras, os ídolos, a retórica. É preciso pensar em uma ficção iconoclasta. ${ }^{31}$

A busca mística, nesse sentido, é pela linguagem que fala, 
pelo toque na borda, pela intransponibilidade do ter-lugar da linguagem. E é esse o silêncio do próprio lugar da linguagem. A experiência do êxtase enquanto calar-se, um não proferir palavra diante do Absoluto (também ele silencioso) para nele se integrar num silêncio que tudo sabe, é um modo de tentar tocar o fundamento negativo (deus) da linguagem; ou, em outros termos, retomando o aforismo 6.44 do Tractatus de Wittgenstein, aos conteúdos da linguagem com os quais dizemos "como o mundo é", a experiência do negativo é a tentativa de ir além e, assim, experimentar o "que o mundo seja".

Chamar o nome silencioso - o impronunciável silêncio sempre dito na linguagem - é a tarefa do poeta. Como lembra Murilo Mendes, o poeta não é senão uma espécie de ordenador do sagrado em um mundo em que a linguagem deformada diz apenas a morte. ${ }^{32}$ Ademais, ele, o poeta, tem na palavra a ordenadora do mundo caótico, isto é, encontra nesse aspecto fundamental (e fundante) da linguagem seu alicerce de maravilhamento e espanto, de alegria e agonia, no que é o mundo. À medida em que se anula, obliterando qualquer materialidade de um eu poético, o poeta percorre o caminho infindável, e de uma conversa infinita, que é a literatura. Não o faz com outra linguagem ou apenas num plano de sublimação entre som e sentido, mas na hesitação do próprio não-lugar essencial (fundamental) da linguagem. E essa "utopia da linguagem, em direção à qual a literatura está a caminho, coincide com o irreparável caráter tópico das proposições significantes: ela não é uma outra palavra, mas somente o seu ter lugar, o halo de silêncio que a delimita e expõe". ${ }^{33}$ Numa pura ex-posição aos sentidos, o poeta, atravessado pela ausência divina, verte palavras que não revelam um inefável (ou, o Inefável), mas, sim, revelam a impossibilidade de - como Kafka pensa ter sabido Ulisses - escapar de um silêncio implacável que excede todo dizer. Apesar de tudo, em luta com a linguagem, o poeta a percebe esperando pela contemplação de seu olhar, como uma sereia terrivelmente silenciosa. Resta ao poeta, portanto, não mais que a coragem de para ela olhar e, sem mais, viver a constante despedida da Besta vítrea que por trás da linguagem se esconde.
32. Cf. MENDES, Murilo.

Papiers. In: Poesia Completa

e Prosa. 1994, pp. 1593-1594.

Há uma tradução publicada em Sopro 54, julho 2011: http://culturaebarbarie.org/ sopro/arquivo/montreal. $\mathrm{html}$ "De modo algum creio na potência do poeta hoje enquanto ordenador do sagrado, pois estamos instalados na dessacralização total, isto é, na desintegração dos signos de amor. Pelo fato de a linguagem ter sido deformada, o drama do poeta se confunde com aquele do homem. Não se sabe mais hoje o valor exato das palavras. Em diversos setores se nos propõe a destruição da linguagem aristotélica. Estou de acordo, ao menos em parte, pois uma tal linguagem corresponde a conceitos ultrapassados. E o que é formidável no nosso mundo atual é que tudo está aí para ser reconstruído. É absolutamente preciso reconstruir a linguagem. E isso jamais será obra de um só homem. Temos perto de nós o exemplo de Mallarmé quem, não obstante tudo o que trouxe de maravilhoso, teve consciência de sua derrota. Assim, na véspera de sua morte, escrevia para sua mulher e sua filha Geneviève: 'E, no entanto, era tão belo!' aquilo que ele quisera fazer, o Livro Órfico da revelação cósmica, o livro da terra. Pois nós estamos engajados, nós estamos na terra. Nossa linguagem deve ser, portanto, uma linguagem concreta, baseada em valores racionais e de acordo com todas as possibilidades do mundo atual".

33. AGAMBEN, Giorgio. $O$ Silêncio das Palavras, 2012. 


\section{Referências}

AGAMBEN, Giorgio. El Lenguaje e la Muerte. Un seminario sobre el lugar de la negatividad. Trad. Tomás Segovia. Valencia: Pre-Textos, 2002.

Infância e História. A destruição da experiência e a origem da história. Trad. Henrique Burigo. Belo Horizonte: Editora UFMG, 2005.

La "Notte Oscura" di Juan de la Cruz. In: CRUZ, Juan de la. Poesie. Trad. Giorgio Agamben. Milano: Giulio Einaudi, 1974.

___. La Potenza del Pensiero. Saggi e conferenze. Vincenza: Neri Pozza, 2005.

O Silêncio das Palavras. Trad. Vinícius Nicastro

Honesko. Documento disponível em: http://flanagens. blogspot.com.br/2012/08/o-silencio-das-palavras.html)

ANSELMO. Proslogium. Translated From The Latin By Sidney Norton Deane, B. A. With An Introduction, Bibliography, And Reprints Of The Opinions Of Leading Philosophers And Writers On The Ontological Argument (Chicago, The Open Court Publishing Company, 1903, reprinted 1926). Documento disponível em: http://www. fordham.edu/halsall/basis/anselm-proslogium.html

CATECISMO DA IGREJA CATÓLICA. Petrópolis: Vozes; São Paulo: Loyola, 1993.

DELEUZE, Gilles; GUATTARI, Félix. Mil Platôs. Capitalismo e esquizofrenia. Vol. II. Trad. Ana Lúcia de Oliveira e Lúcia Cláudia Leão. São Paulo: Ed. 34, 1997.

DERRIDA, Jacques. Salvo o Nome. Trad. Nicia Adan Bonatti. Campinas: Papirus, 1995.

GIVONE, Sergio. Historia de la Nada. Trad. Alejo González e Demian Orosz. Buenos Aires: Adriana Hidalgo, 2001.

HEIDEGGER, Martin. A Caminho da Linguagem. Trad. Márcia Sá Cavalcante Schuback. Petrópolis: Vozes; Bragança Paulista: São Francisco, 2003.

MENDES, Murilo. Papiers. In: Poesia Completa e Prosa. Org. Luciana Stegagno Picchio. Rio de Janeiro: Nova Aguilar, 1994. 
NANCY, Jean-Luc. L'évidence du mystère. In: Le Voyage Initiatique. Paris: Albin Michel, 2011.

. O nome de Deus em Blanchot. Trad. Vinícius Nicastro Honesko. Documento disponível em: http://flanagens.

blogspot.com.br/2013/03/o-nome-de-deus-em-blanchot.html

Ser Singular Plural. Trad. Antonio Tudela Sancho.

Madrid: Arena Libros, 2006.

PIO XII. Humani Generis. Sobre opiniões falsas que ameaçam a doutrina católica. Documento disponível em: http://www.vatican.va/holy_father/pius_xii/encyclicals/ documents/hf_p-xii_enc_12081950_humani-generis_po.html

PUECH, Henri-Charles. En Quête de la Gnose. I. La gnose et le temps. Paris: Gallimard, 2006.

SCHOLEM, Gershom. Il Nome di Dio e la Teoria Cabbalistica del Linguaggio. Trad. Adriano Fabris. Milano: Adelphi, 2005.

TAUBES, Jacob. Del culto a la cultura. Elementos para una critica de la razón histórica. Trad. Silvia Villegas. Buenos Aires: Katz Editores, 2007.

VIRNO, Paolo. Quando il verbo si fa carne. Linguaggio e natura umana. Torino: Bollati Boringhieri, 2003.

WITTGENSTEIN, Ludwig. Tractatus Lógico-philosophicus. Trad. José Arthur Giannotti. São Paulo: Companhia Editora Nacional; USP, 1968. 
